\title{
E. coli Nickel-Iron Hydrogenase 1 Catalyses Non-native Reduction of Flavins: Demonstration for Alkene Hydrogenation by Old Yellow Enzyme
}

Shiny Joseph Srinivasan, ${ }^{[a]}$ Sarah E. Cleary, ${ }^{[a]}$ Caroline E. Paul, ${ }^{[b]}$ Miguel A. Ramirez ${ }^{[a]}$ and Kylie A. Vincent ${ }^{[a] *}$

[a] Department of Chemistry, University of Oxford, Inorganic Chemistry Laboratory, South Parks Road, Oxford, United Kingdom OX13QR

*E-mail: kylie.vincent@chem.ox.ac.uk

[b] Department of Biotechnology, Delft University of Technology, Van der Maasweg 9, 2629 HZ Delft, The Netherlands

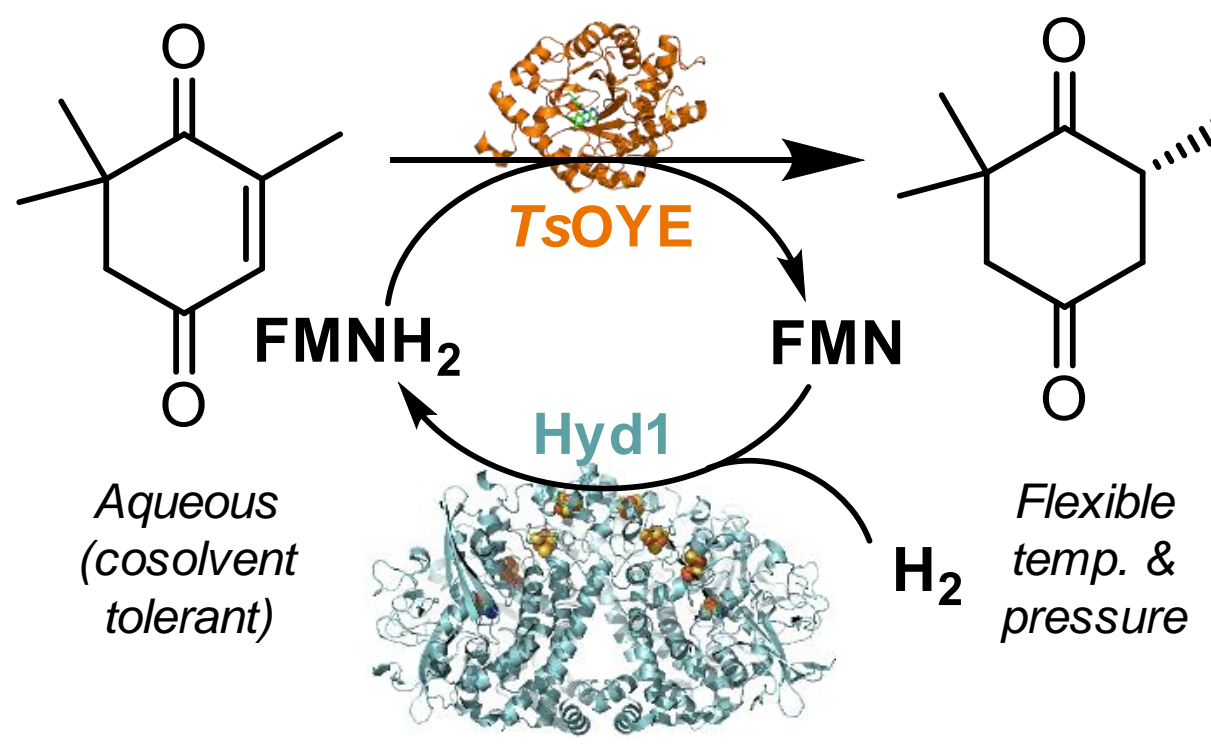

New enzyme activity

Abstract: A new activity for the [NiFe] uptake hydrogenase 1 of Escherichia coli (Hyd1) is presented. Direct reduction of biological flavin cofactors FMN and FAD is achieved using $\mathrm{H}_{2}$ as a simple, completely atom-economical reductant. The robust nature of Hyd1 is exploited for flavin reduction across a broad range of temperatures $\left(25-70{ }^{\circ} \mathrm{C}\right)$ and extended reaction time. The utility of this system as a simple, easy to implement $\mathrm{FMNH}_{2}$ regenerating system is then demonstrated by supplying reduced flavin to an Old Yellow Enzyme to support asymmetric alkene reductions with up to $100 \%$ conversion. High Hyd1 turnover frequencies (up to $340 \mathrm{~s}^{-1}$ ) and total turnover numbers $(>10,000,000)$ during flavin recycling show the promise of this biocatalytic system. 
As the need to make chemical manufacturing more sustainable becomes urgent, academic and industrial fields increasingly turn to biotechnology. ${ }^{[1]}$ Enzymes provide many advantages over other catalysts: they are renewable, biodegradable, nonhazardous, and provide high selectivity. The once-limited scope of known enzyme reactions has rapidly expanded, aided by enzyme engineering and ongoing discovery and characterisation of new enzymatic functions. ${ }^{[2,3]}$

Many useful enzymes for biotechnology employ flavin moieties (e.g. FMN, FAD; Scheme 1) as prosthetic groups or cofactors. These include halogenases (chlorination, bromination, iodination), ${ }^{[4]}$ ene-reductases (activated alkene reduction), ${ }^{[5]}$ and flavoprotein monooxygenases (epoxidations, hydroxylations, Baeyer-Villiger oxidation). ${ }^{[6]}$ Potential applications of these enzymes are natural product and pharmaceutical synthesis, ${ }^{[7]}$ biodegradation of environmental pollutants, ${ }^{[8]}$ and non-native light-driven reactions (Figure S2). ${ }^{[9]}$ These reactions require one equivalent of the reduced cofactors $\mathrm{FMNH}_{2}$ or $\mathrm{FADH}$. To lower cost and waste, a catalytic quantity of more stable oxidised FMN/FAD is supplied, and is reduced (Scheme 1) in situ by means of photochemistry, electrochemistry, metal-catalysis or biocatalysis (Figure S2). ${ }^{[4,5,10]}$

In general, biocatalysed cofactor recycling is the most straightforward option for coupling with flavoenzyme reactions because the alternative catalysts can face biocompatibility challenges (e.g. mutual inactivation, mismatched ideal solvent, $\mathrm{pH}$ or temperature). ${ }^{[4,11]} \mathrm{A}$ common, yet cumbersome, strategy is to regenerate the flavin using an $N A D(P) H$-dependent reductase which produces $\mathrm{FMNH}_{2}$ or $\mathrm{FADH}_{2}$ at the expense of $\mathrm{NAD}(\mathrm{P}) \mathrm{H}^{[12]}$ or its analogues. ${ }^{[13]} \mathrm{A}$ catalytic quantity of the reduced nicotinamide cofactors must in turn be regenerated due to their high cost. This is typically achieved via glucose dehydrogenasecatalysed oxidation of glucose, which elevates cost, waste and downstream processing. ${ }^{[14]}$ The complexity of currently-available recycling systems for reduced flavins may explain the under-utilisation of flavoenzymes in biotechnology, despite the important reactions they catalyse. ${ }^{[15]}$<smiles>[R]OP(=O)(O)OC[C@@H](O)[C@@H](O)[C@@H](O)Cn1c2nc(=O)[nH]c(=O)c-2nc2cc(C)c(C)cc21</smiles>

$\mathbf{R}=\mathbf{H}, \mathbf{F M N}$

$R=$ adenosine monophosphate (below), FAD<smiles>[R]OP(=O)(O)OC[C@@H](O)[C@@H](O)[C@@H](O)CN1c2cc(C)c(C)cc2Nc2c1[nH]c(=O)[nH]c2=O</smiles>

$\mathrm{FMNH}_{2}$ or $\mathrm{FADH}_{2}$<smiles>CCP(=O)([O-])OC[C@H]1O[C@@H](n2cnc3c(N)ncnc32)[C@H](O)[C@@H]1O</smiles>

Scheme 1. Oxidised (left) and reduced (right) FMN or FAD cofactors

Alternatively, $\mathrm{H}_{2}$ has previously been demonstrated for cleaner enzymatic NADH cofactor recycling. ${ }^{[16,17]}$ The soluble hydrogenase from Cupriavidus necator (formerly Ralstonia eutropha) natively uses $\mathrm{H}_{2}$ to provide electrons for $\mathrm{NAD}^{+}$reduction at a prosthetic flavin cofactor. $^{[17]}$ Reduction of flavin substrates by this enzyme under $\mathrm{H}_{2}$ has also been reported, ${ }^{[18]}$ presumably at the $\mathrm{NAD}^{+}$binding site. However, this enzyme is complex to express and lacks stability at elevated temperatures. ${ }^{[19,20]}$ This inspired us to test whether a simple hydrogenase (Figure 1) could be suitable for $\mathrm{H}_{2}$-driven flavin reduction. The thermodynamic potential for the $\mathrm{H}^{+} / \mathrm{H}_{2}$ couple $(-0.472 \mathrm{~V}, \mathrm{pH} 8)$ relative to the flavin potential $(-0.230 \mathrm{~V}, \mathrm{pH} 8$, Scheme 1$),{ }^{[21]}$ makes reduction of flavin by $\mathrm{H}_{2}$ thermodynamically 
favourable. We selected E. coli [NiFe]-hydrogenase (Hyd1), which is a good $\mathrm{H}_{2}$ oxidiser ${ }^{[22,23]}$ and well-characterised in terms of X-ray crystal structures ${ }^{[24,25]}$ and spectroscopy. ${ }^{[23,26]} \mathrm{Hyd} 1$ is natively expressed in $E$. coli and, unlike many hydrogenases, ${ }^{[27]}$ it is $\mathrm{O}_{2}$-tolerant ${ }^{[23]}$ and active over a wide $\mathrm{pH}$ range. ${ }^{[28]}$ Like other uptake hydrogenases, the basic unit of Hyd1 is a heterodimer of the large subunit (HyaB) housing the [NiFe] active site, and the small subunit $(\mathrm{HyaA})$ housing the iron-sulfur cluster electron transfer relay. Natively, Hyd1 is coupled to a cytochrome electron acceptor, and exists as a homodimer of HyaAB units. The isolated enzyme comprises predominantly dimeric $\mathrm{HyaAB}^{[29]}$ and our preparation lacks the cytochrome (Figure S1).

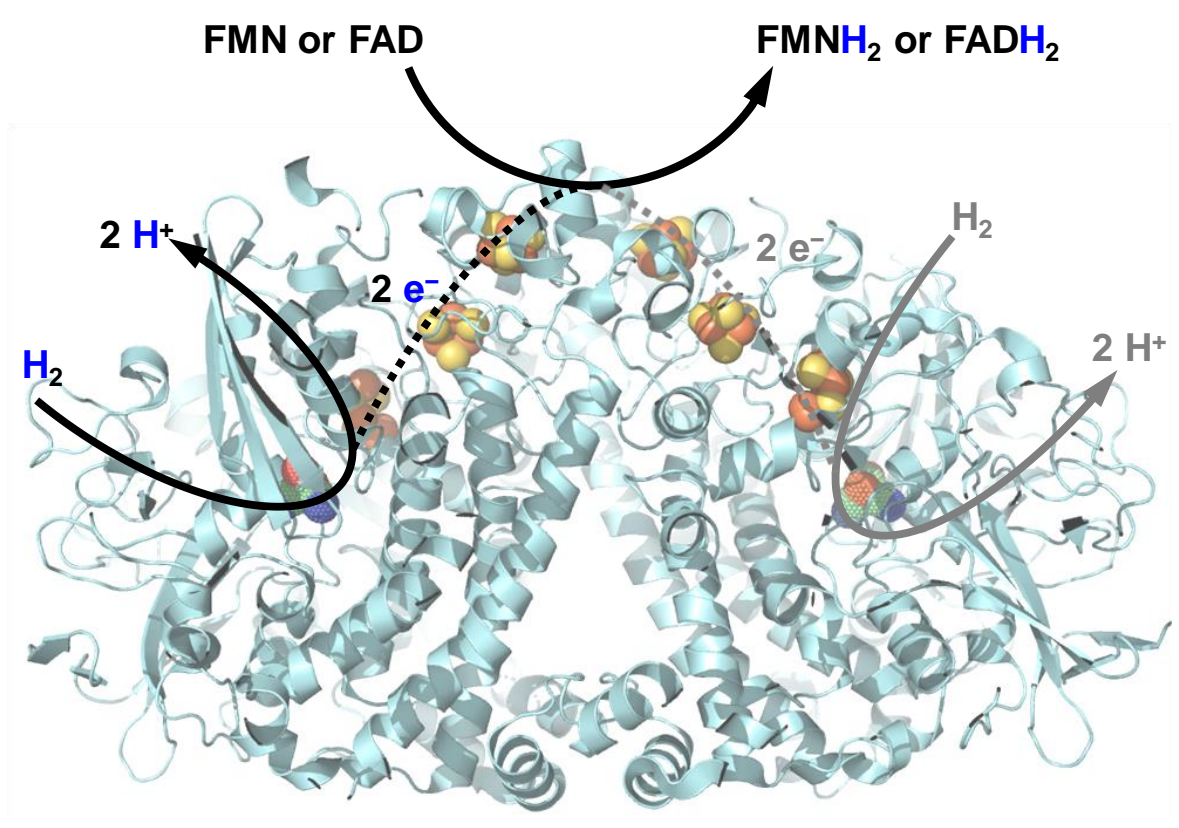

Figure 1. Two-electron flavin reduction by $\mathrm{Hyd} 1 . \mathrm{H}_{2}$ oxidation at the [NiFe] active site (green, red, blue) provides 2 electrons that are transferred to the surface of the protein via FeS clusters (yellow, orange). The figure, showing the homodimer of $\mathrm{HyaAB}$ units, was prepared using PyMOL ${ }^{\mathrm{TM}}$ 2.3.4

(PDB: 6FPW).

The $\mathrm{H}_{2}$ oxidation activity of Hyd1 is typically measured using the artificial electron acceptor benzyl viologen in colourimetric assays. ${ }^{[28]}$ Electrons from $\mathrm{H}_{2}$ oxidation at the [NiFe] active site (Figure 1) are relayed through FeS clusters where, evidence suggests, benzyl viologen reduction occurs rather than directly at the [NiFe] active site. ${ }^{[30]}$ Herein, we demonstrate that both FMN and FAD can accept electrons from $\mathrm{H}_{2}$ oxidation by Hyd1 to generate $\mathrm{FMNH}_{2}$ and $\mathrm{FADH}_{2}$, and show that Hyd1 can be used as an effective $\mathrm{FMNH}_{2}$ regeneration system to support asymmetric alkene reduction by an Old Yellow Enzyme (OYE)-type ene-reductase.

Figure 2 shows the results of in situ UV-visible spectrophotometric assays to explore FMN and $\mathrm{FAD}$ reduction by Hyd1 (38 $\mu \mathrm{g}$, produced and isolated in accord with S1.2, Supporting Information) under $\mathrm{H}_{2}$ (General Procedure A, Supporting Information). The flavin moiety of FMN gives $\lambda_{\max }$ at $445 \mathrm{~nm}$ and FAD at $450 \mathrm{~nm}$, both of which bleach upon two-electron reduction (Figure $2 \mathrm{~A}-\mathrm{B}$; see Figure $\mathrm{S} 8$ for spectra of fully reduced $\mathrm{FMN}$ ). ${ }^{[31,32]}$ The decrease in [oxidised flavin] over time was used to calculate initial enzyme activity (Figure 2C-D). Control experiments indicated that omission of $\mathrm{Hyd} 1 \mathrm{or}_{2}$ led to negligible flavin reduction (Figures S3-S4).

Upon addition of Hyd1, a lag phase was observed during FMN and FAD reduction, which is attributed to the well-characterised $\mathrm{H}_{2}$-dependent activation phase for aerobically purified Hyd1. ${ }^{[23]}$ Later experiments (when indicated) used $\mathrm{Hyd} 1$ that was first activated under a $\mathrm{H}_{2}$ atmosphere. ${ }^{[33]}$ The lag phase was followed by a decrease in absorbance consistent with 
$\mathrm{FMNH}_{2} / \mathrm{FADH}_{2}$ formation, and clear isosbestic points at $330 \mathrm{~nm}$ corroborate a lack of side products. Specific initial activities for FMN and FAD reduction $\left(76\right.$ and $32 \mathrm{nmol} \mathrm{min}{ }^{-1} \mathrm{mg}^{-1}$ Hyd1, respectively) were determined during the linear reaction phase. The higher activity for reduction of FMN compared with FAD cannot be attributed to thermodynamic driving force since both cofactors have similar reduction potentials, ${ }^{[21]}$ but could relate to the cofactors' ability to interact at the protein surface.
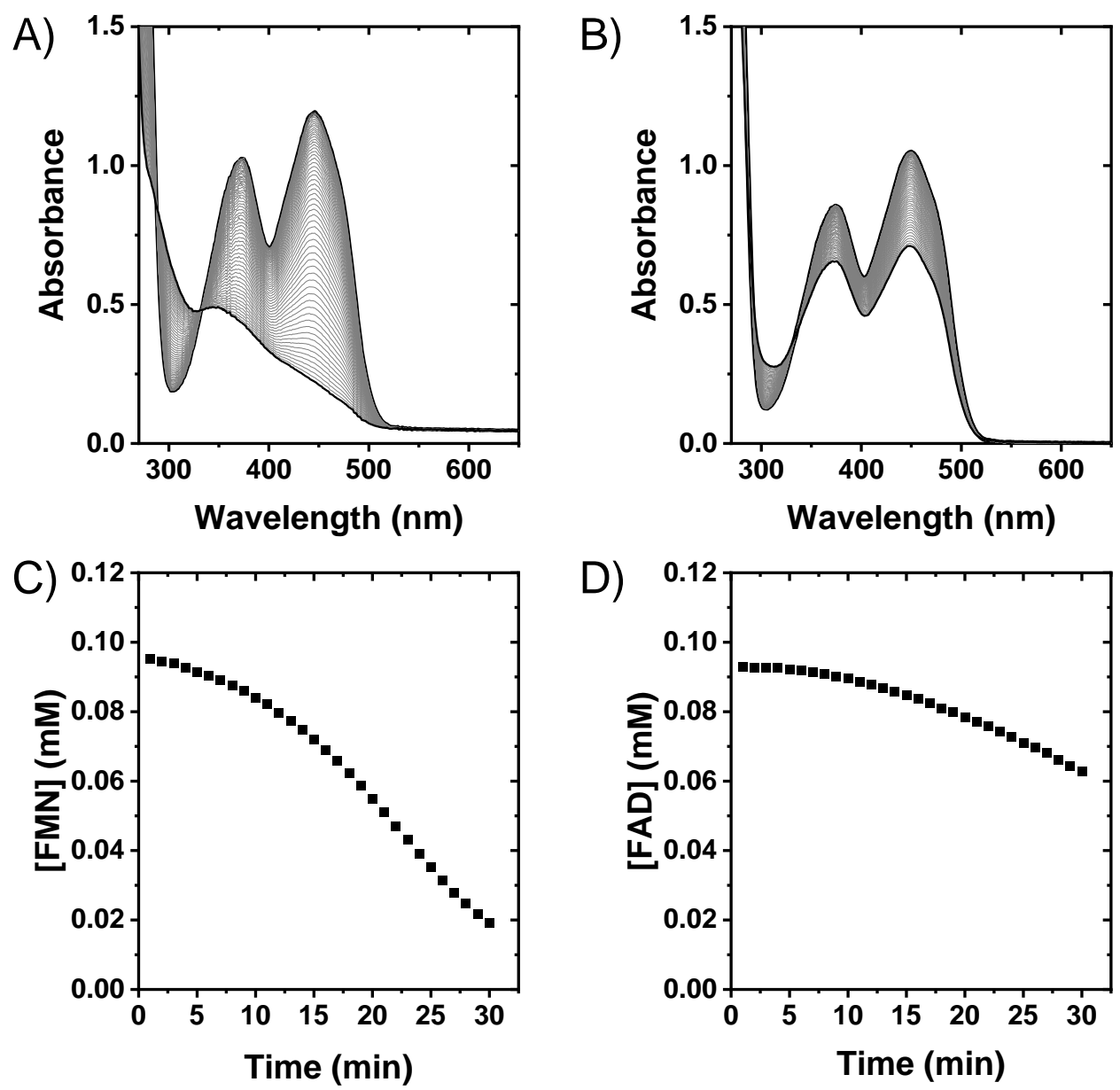

Figure 2. Activity assay for $\mathrm{H}_{2}$-driven $\mathrm{Hyd} 1$ reduction of flavin measured by in situ UV-visible spectroscopy. A) Hyd1 reducing FMN. B) Hyd1 reducing FAD. C) Calculated [FMN] based on $\lambda_{\max }=$ $445 \mathrm{~nm}\left(\varepsilon=12.50 \mathrm{mM}^{-1} \mathrm{~cm}^{-1}\right)$. D) Calculated [FAD] based on $\lambda_{\max }=450 \mathrm{~nm}\left(\varepsilon=11.30 \mathrm{mM}^{-1} \mathrm{~cm}^{-1}\right)$.

Reaction conditions: General Procedure A in Tris- $\mathrm{HCl}$ buffer $\left(50 \mathrm{mM}, \mathrm{pH} 8.0,25^{\circ} \mathrm{C}\right)$.

Hyd1 is known to be robust which inspired us to test $\mathrm{H}_{2}$-driven flavin reduction activity at different temperatures $\left(25-70{ }^{\circ} \mathrm{C}\right.$, General Procedure A). Percentage conversion of FMN and FAD to the reduced forms after 30 min reaction time increased with temperature (Figure 3 ), though FMN reduction was not enhanced past $60^{\circ} \mathrm{C}$. This suggests that Hyd1 is likely to open new doors to cofactor recycling for flavoenzymes with optimal activity at higher temperatures. 

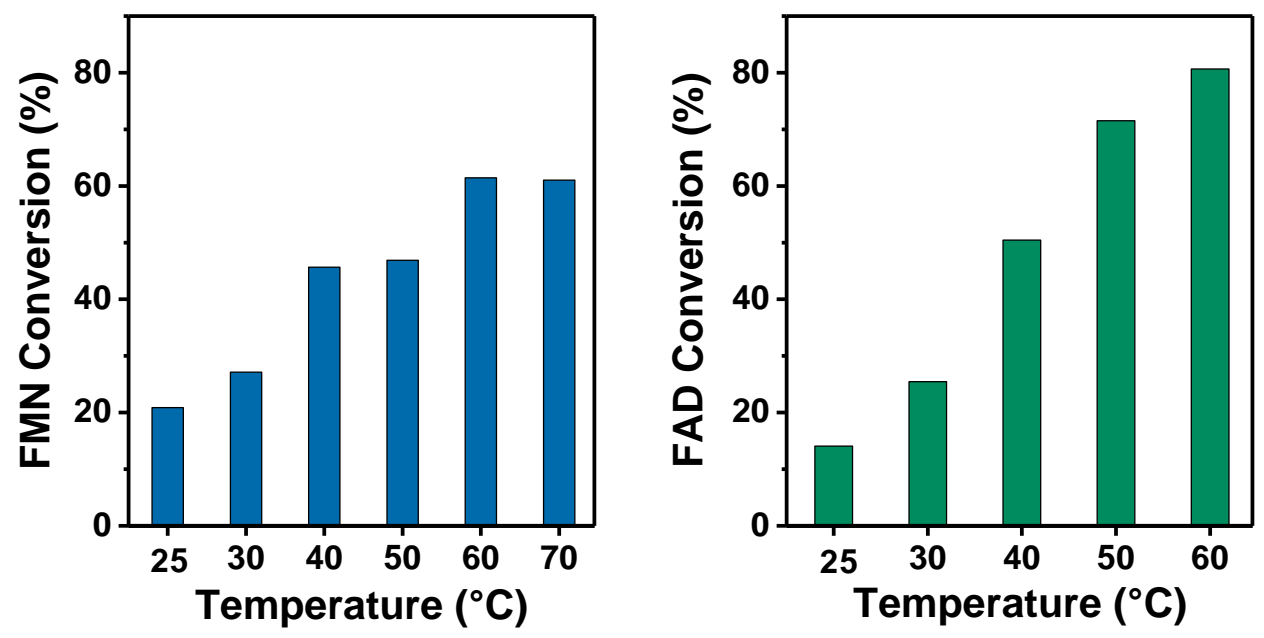

Figure 3. Hyd1-catalysed flavin reduction at different temperatures. Reaction conditions: General Procedure A (Supporting Information) in phosphate buffer $(50 \mathrm{mM}, \mathrm{pH} 8.0)$. Conversion was calculated after 30 min using UV-visible spectroscopy.

In order to demonstrate the utility of Hyd1 in biotechnologically-relevant flavin recycling, we coupled Hyd1-catalysed flavin reduction with the OYE-type ene-reductase from Thermus scotoductus, TSOYE, ${ }^{[34,35]}$ to catalyse enantioselective reduction of ketoisophorone $(1)$ to $(R)$ levodione (2, Scheme 2). Reactions were conducted according to General Procedure B (Supporting Information) and monitored using chiral-phase GC-FID after extraction of the mixture into ethyl acetate (Figure S9). Enantiomeric excess (ee) was always $>99 \%$ at the first time point but decreased to $86-92 \%$ from slow racemisation under alkaline conditions. Control experiments confirmed that each component is required for conversion (Table S1).<smiles>CC1=CC(=O)CC(C)(C)C1=O</smiles>

1
Hyd1, Ts OYE

$\mathrm{H}_{2}$ (1 bar), FMN (cat.)

Tris-HCl (50 mM, pH 8.0) 1 vol\% DMSO room temp. $\left(20-22{ }^{\circ} \mathrm{C}\right)$

Scheme 2. Two-enzyme asymmetric alkene hydrogenation.

Quantitative conversion and the highest Hyd1 turnover frequency (TOF, $344 \mathrm{~s}^{-1}$ ) were achieved with $0.5 \mathrm{mM} \mathrm{FMN}$ and $2 \mathrm{mM} 1$ (entry 1, Table 1). This TOF compares with or improves upon two-component $\mathrm{NAD}(\mathrm{P}) \mathrm{H}$ :flavin reductases. ${ }^{[15,36]}$

When 0.1 mM FMN was used with varying [1] (entries 2-5), up to $97 \mathrm{FMN}$ turnovers (TN) were achieved. This is comparable to the FMN TN reported for a formate-driven homogeneous $\mathrm{Rh}$-catalysed method for $\mathrm{FMNH}_{2}$ recycling coupled to TSOYE. ${ }^{[34]}$ That system required careful balance between enzyme and $\mathrm{Rh}$-catalyst loading to prevent nonenantioselective alkene reduction by $\mathrm{FMNH}_{2}$ or $\left[\mathrm{Cp}^{*} \mathrm{Rh}(\mathrm{bpy}) \mathrm{H}\right]^{+}$, which was not an appreciable issue with our biocatalytic system (Table S1).

The highest Hyd1 total turnover number (TTN, 10,246,000) was achieved using $10 \mathrm{mM} 1$ (entry 4). This TTN is of an appropriate order of magnitude for industrial catalysis, ${ }^{[3]}$ but there remains room for further optimisation to that end. At $20 \mathrm{mM} \mathrm{1}$, Hyd1 TTN and conversion were boosted using 4 bar $\mathrm{H}_{2}$, which also improved Hyd1 TOF from $88 \mathrm{~s}^{-1}$ to 108 $\mathrm{s}^{-1}$ (compare entries 5-6). 
Table 1. $\mathrm{H}_{2}$-driven enzymatic alkene reduction under various conditions

\begin{tabular}{cccccc}
\hline Entry & $\begin{array}{c}{[1]} \\
(\mathrm{mM})\end{array}$ & $\begin{array}{c}{[\mathrm{FMN}]} \\
(\mathrm{mM})\end{array}$ & $\begin{array}{c}\text { Conv. } \\
\text { to 2 } \\
(\%)^{\mathrm{a}}\end{array}$ & Hyd1 TTN & $\begin{array}{c}\text { FMN } \\
\text { TN }^{\mathrm{b}}\end{array}$ \\
\hline 1 & 2 & 0.5 & 100 & $2,142,000$ & 4 \\
2 & 2 & 0.1 & 100 & $2,105,000$ & 20 \\
3 & 5 & 0.1 & $\begin{array}{c}95 \\
\{100\}\end{array}$ & $5,263,000$ & 50 \\
4 & 10 & 0.1 & $62\{97\}$ & $10,246,000$ & 97 \\
5 & 20 & 0.1 & $24\{37\}$ & $7,822,000$ & 74 \\
$6^{c}$ & 20 & 0.1 & $\{44\}$ & $9,332,000$ & 88
\end{tabular}

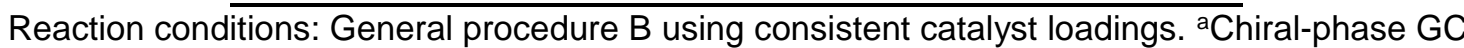
conversion to 2 at $15 \mathrm{~h}$ \{and $24 \mathrm{~h}\}$. ${ }^{\text {bHd }} 1$ total turnover number (mol 2 per mol Hyd1) and FMN turnover number (mol 2 per mol flavin) were determined at the end of the reaction. ${ }^{\circ} 4$ bar $\mathrm{H}_{2}$.

Like Hyd1, TsOYE has enhanced activity at elevated temperatures, ${ }^{[34]}$ therefore entry 4 was replicated at $35{ }^{\circ} \mathrm{C}$ (data not tabulated): Hyd1 TOF nearly doubled to $160 \mathrm{~s}^{-1}$ and full conversion was achieved after $24 \mathrm{~h}$, however GC-FID showed that some of $\mathbf{1}$ and 2 likely evaporated.

To test stability over time, Hyd1 $(57 \mu \mathrm{g})$ was activated under $\mathrm{H}_{2}$ at $22{ }^{\circ} \mathrm{C}$ for $58 \mathrm{~h}$, then incubated in $0.08 \mathrm{mM} F M N$ under $\mathrm{H}_{2}(1 \mathrm{bar})$ in a sealed vessel for $62 \mathrm{~h}$. Upon release of $\mathrm{H}_{2}$, $\mathrm{FMNH}_{2}$ partially oxidised under the $\mathrm{N}_{2}$ atmosphere to $0.05 \mathrm{mM}$ FMN (determined using UVvisible spectroscopy). The Hyd1 and $\mathrm{FMN} / \mathrm{FMNH}_{2}$ solution was placed back under $\mathrm{H}_{2}$, and full reduction to $\mathrm{FMNH}_{2}$ was noticed after $3.5 \mathrm{~h}$ (see Figure S8), which demonstrates appreciable Hyd1 stability over $125 \mathrm{~h}$ (>5 days).

The simplified, $\mathrm{H}_{2}$-driven biocatalysed flavin recycling method coupled with TSOYE led to high Hyd1 TOF and TTN (2-10 million) that correspond with commercial grade enzymes. ${ }^{[38]}$ Further modifications to Hyd1, which is tolerant of mutagenesis, ${ }^{[25,33]}$ might enhance the nonnative activity. Additionally, process development is underway to improve industriallyrelevant metrics such as cofactor TN. This proof of concept work shows that the robust Hyd1, tolerant to a range of conditions, is a promising catalyst to bring clean flavin recycling into biotechnology.

\section{Acknowledgements}

This research was supported financially by awards from European Research Council (BiocatSusChem ERC-2018-CoG 819580), Biotechnology and Biological Sciences Research Council (BBSRC, BB/R018413/1) and Engineering and Physical Sciences Research Council (EPSRC, IB Catalyst EP/N013514/1) to K.A.V. We are grateful to Dr Rhiannon Evans (University of Oxford) for helpful discussions, and to Wangzhe Li and Sophie Kendall-Price (University of Oxford) for providing Hyd1 with and without cytochrome.

Keywords: Cofactor recycling $\bullet$ biocatalysis $\bullet$ flavoenzyme $\cdot$ hydrogenation $\bullet$ asymmetric catalysis 


\section{References:}

[1] R. A. Sheldon, J. M. Woodley, Chem. Rev. 2018, 118, 801-838.

[2] H. A. Bunzel, X. Garrabou, M. Pott, D. Hilvert, Curr. Opin. Struc. Biol. 2018, 48, 149156.

[3] K. Chen, F. H. Arnold, Nat. Catal. 2020, 3, 203-213.

[4] J. Latham, E. Brandenburger, S. A. Shepherd, B. R. K. Menon, J. Micklefield, Chem. Rev. 2018, 118, 232-269.

[5] C. K. Winkler, K. Faber, M. Hall, Curr. Opin. Biotechnol. 2018, 43, 97-105.

[6] R. D. Ceccoli, D. A. Bianchi, D. V. Rial, Front. Microbiol. 2014, 5, 25.

[7] S. A. Baker Dockrey, A. R. H. Narayan, Tetrahedron 2019, 75, 1115-1121.

[8] S. Adak, T. P. Begley, Biochemistry 2019, 58, 1181-1183.

[9] K. F. Biegasiewicz, S. J. Cooper, X. Gao, D. G. Oblinsky, J. H. Kim, S. E. Garfinkle, L. A. Joyce, B. A. Sandoval, G. D. Scholes, T. K. Hyster, Science 2019, 364, 11661169.

[10] H. S. Toogood, N. S. Scrutton, ACS Catal. 2018, 8, 3532-3549.

[11] F. Rudroff, M. D. Mihovilovic, H. Gröger, R. Snajdrova, H. Iding, U. T. Bornscheuer, Nat. Catal. 2018, 1, 12-22.

[12] L. Sellés Vidal, C. L. Kelly, P. M. Mordaka, J. T. Heap, Biochim. Biophys. Acta, Proteins Proteomics 2018, 1866, 327-347.

[13] M. Ismail, L. Schroeder, M. Frese, T. Kottke, F. Hollmann, C. E. Paul, N. Sewald, ACS Catal. 2019, 9, 1389-1395.

[14] J. P. Adams, M. J. B. Brown, A. Diaz-Rodriguez, R. C. Lloyd, G. Roiban, Adv. Synth. Catal. 2019, 361, 2421-2432.

[15] T. Heine, W. van Berkel, G. Gassner, K.-H. van Pée, D. Tischler, Biology 2018, 7, 42.

[16] H. A. Reeve, L. Lauterbach, O. Lenz, K. A. Vincent, ChemCatChem 2015, 7, 34803487.

[17] L. Lauterbach, O. Lenz, K. A. Vincent, FEBS J. 2013, 280, 3058-3068.

[18] K. Schneider, H. G. Schlegel, Biochim. Biophys. Acta 1976, 452, 66-80.

[19] O. Lenz, L. Lauterbach, S. Frielingsdorf, in Methods Enzymol. (Ed.: F.A. Armstrong), Academic Press Inc., 2018, pp. 117-151.

[20] N. Herr, J. Ratzka, L. Lauterbach, O. Lenz, M. B. Ansorge-Schumacher, J. Mol. Catal. B. Enzym. 2013, 97, 169-174.

[21] S. Vogt, M. Schneider, H. Schä Fer-Eberwein, G. Nö, Anal. Chem. 2014, 86, 75307535.

[22] P. Wulff, C. C. Day, F. Sargent, F. A. Armstrong, PNAS 2014, 111, 6606-6611.

[23] M. J. Lukey, A. Parkin, M. M. Roessler, B. J. Murphy, J. Harmer, T. Palmer, F. Sargent, F. A. Armstrong, J. Biol. Chem. 2010, 285, 3928-38.

[24] A. Volbeda, P. Amara, C. Darnault, J.-M. Mouesca, A. Parkin, M. M. Roessler, F. A. Armstrong, J. C. Fontecilla-Camps, PNAS 2012, 109, 5305-5310.

[25] R. M. Evans, E. J. Brooke, S. A. M Wehlin, E. Nomerotskaia, F. Sargent, S. B. Carr, S. E. V Phillips, F. A. Armstrong, Nat. Chem. Biol. 2015, 12, 46-50. 
[26] R. Hidalgo, P. A. Ash, A. J. Healy, K. A. Vincent, Angew. Chem. Int. Ed. 2015, 54, 7110-7113.

[27] K. A. Vincent, A. Parkin, F. A. Armstrong, Chem. Rev. 2007, 107, 4366-4413.

[28] B. J. Murphy, F. Sargent, F. A. Armstrong, Energy Environ. Sci. 2014, 7, 1426-1433.

[29] P. Wulff, C. Thomas, F. Sargent, F. A. Armstrong, J. Biol. Inorg. Chem. 2016, 21, 121-134.

[30] C. Pinske, S. Krüger, B. Soboh, C. Ihling, M. Kuhns, M. Braussemann, M. Jaroschinsky, C. Sauer, F. Sargent, A. Sinz, et al., Arch. Microbiol. 2011, 193, 893903.

[31] P. Macheroux, in Methods Mol. Biol. (Eds.: S.K. Chapman, G.A. Reid), Humana Press, Totowa, NJ, 1999, pp. 1-7.

[32] A. M. Edwards, in Methods Mol. Biol. (Eds.: S. Weber, E. Schleiker), Humana Press, New York, 2014, pp. 3-13.

[33] R. M. Evans, P. A. Ash, S. E. Beaton, E. J. Brooke, K. A. Vincent, S. B. Carr, F. A. Armstrong, J. Am. Chem. Soc. 2018, 140, 10208-10220.

[34] J. Bernard, E. van Heerden, I. W. C. E. Arends, D. J. Opperman, F. Hollmann, ChemCatChem 2012, 4, 196-199.

[35] D. J. Opperman, B. T. Sewell, D. Litthauer, M. N. Isupov, J. A. Littlechild, E. van Heerden, Biochem. Biophys. Res. Commun. 2010, 393, 426-431.

[36] B. R. K. Menon, J. Latham, M. S. Dunstan, E. Brandenburger, U. Klemstein, D. Leys, C. Karthikeyan, M. F. Greaney, S. A. Shepherd, J. Micklefield, Org. Biomol. Chem. 2016, 14, 9354-9361.

[37] J. Dong, E. Fernández-Fueyo, F. Hollmann, C. E. Paul, M. Pesic, S. Schmidt, Y. Wang, S. Younes, W. Zhang, Angew. Chem. Int. Ed. 2018, 57, 9238-9261.

[38] T. A. Rogers, A. S. Bommarius, Chem. Eng. Sci. 2010, 65, 2118-2124. 


\section{E. coli Nickel-Iron Hydrogenase 1 Catalyses Non-native Reduction of Flavins:}

Demonstration for Alkene Hydrogenation by Old Yellow Enzyme.

\section{Contents}

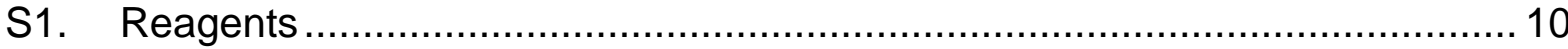

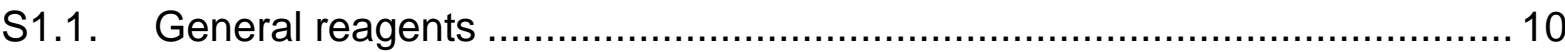

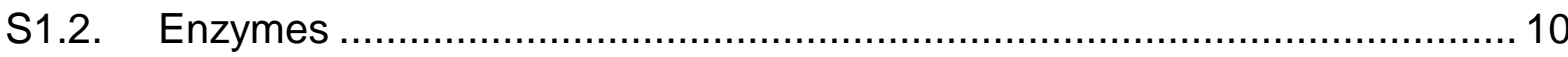

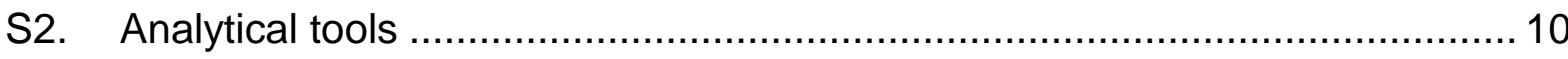

S2.1. UV-visible spectroscopy to monitor flavin reduction ............................. 10

S2.2. Chiral phase GC-FID to monitor alkene reductions .............................. 11

S3. Experimental procedures.................................................................... 12

S3.1. General Procedure A (Flavin reduction) ............................................ 12

S3.2. General Procedure B (Alkene reduction) .......................................... 12

S3.3. General Procedure C (Preparing samples for chiral GC analysis) ............. 12

S4. Supplementary data and results .................................................. 13

S4.1. Control experiments to confirm role of $\mathrm{Hyd} 1$ and $\mathrm{H}_{2}$ in flavin reduction ...... 14

S4.2. Reduction of FMN under $\mathrm{H}_{2}$ using Hyd1 enzyme fractions that contain or are lacking the cytochrome............................................................................... 16

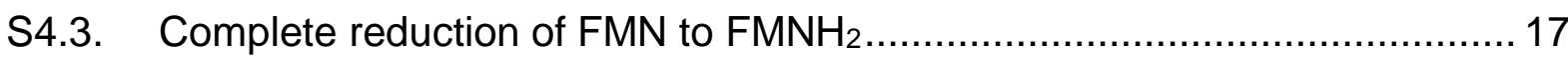

S4.4. Control experiments for $\mathrm{H}_{2}$-driven ketoisophorone reduction .................... 18

S4.5. Exemplary chiral-phase GC-FID spectra of enzymatic $\mathrm{H}_{2}$-driven reduction of

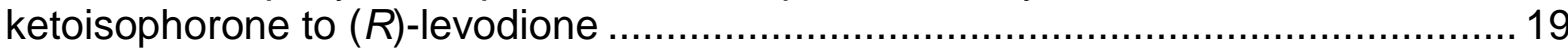

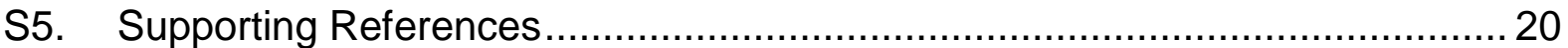




\section{S1. Reagents}

\section{S1.1. General reagents}

Buffer salts (Sigma-Aldrich), FAD (disodium salt, $\geq 98 \%$, Cayman Chemical Company), and FMN (monosodium salt dihydrate, Applichem Panreac) were all used as received. Ketoisophorone (1, 2,6,6-trimethyl-2-cyclohexene-1,4-dione) was purchased from SigmaAldrich with $\geq 98 \%$ purity. $(6 R)$-Levodione $((R)-2)$, was obtained by Baker's yeast fermentation and was a gift from Dr. Adrie Straathof from the Delft University of Technology. GC standard rac-2 was prepared following literature procedure. ${ }^{[1]}$ All aqueous solutions were prepared with deoxygenated MilliQ water (Millipore, $18 \mathrm{M} \Omega \mathrm{cm}$ ).

\section{S1.2. Enzymes}

The hydrogenase (E. coli hydrogenase 1, Hyd1) was produced by homologous overexpression of the genes encoding the structural subunits of the enzyme and key maturases. After Hyd1 overexpression under anaerobic bacterial growth, the enzyme was isolated following published protocols (described in the caption to Figure S1). ${ }^{[2]}$ The Thermus scotoductus ene-reductase of the Old Yellow Enzyme family (TSOYE) ${ }^{[3,4]}$ was produced and purified following published protocols, and stored at $-20^{\circ} \mathrm{C}$ as a $200 \mu \mathrm{M}$ solution in MOPS$\mathrm{NaOH}$ buffer (20 mM, pH 7.0).

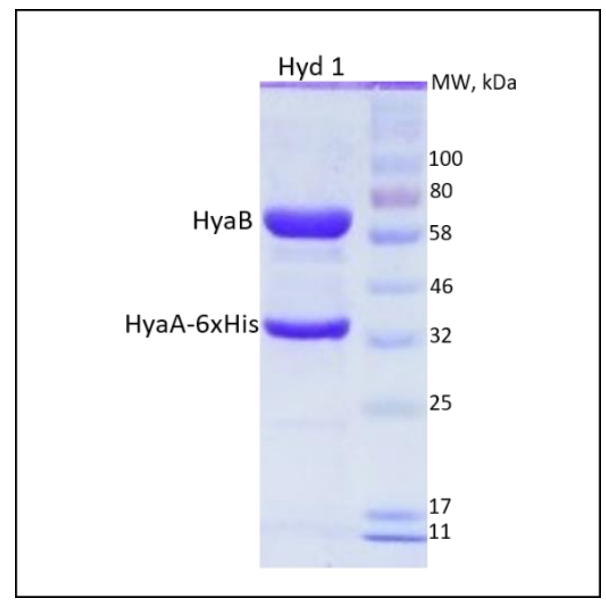

Figure S1. SDS-PAGE analysis of purified Hyd1.

Protein composition and purity in the Hyd1 samples used during all experiments, except those in Section S4.2. After overexpression, the Hyd1 enzyme was purified by Immobilised Metal Affinity Chromatography in a Nickel-NTA prepacked column. After elution with imidazole buffer, the protein was further purified by Size Exclusion Chromatography using a HiLoad 16/600 Superdex 200 pg gelfiltration column (GE Healthcare, UK). Subsequently, the enzyme was buffer-exchanged into Tris $\mathrm{HCl}$ buffer (20 mM Tris- $\mathrm{HCl}$ pH 7.2, $350 \mathrm{mM} \mathrm{NaCl}, 0.02 \%$ Triton X, $1 \mathrm{mM} \mathrm{DTT})$, concentrated and stored

$$
\text { at }-80^{\circ} \mathrm{C} \text {. }
$$

\section{S2. Analytical tools}

\section{S2.1. UV-visible spectroscopy to monitor flavin reduction}

UV-visible spectra were recorded by a Cary 60 spectrophotometer with a cell holder (Agilent) and a Peltier accessory for temperature control using a quartz cuvette (path length $1 \mathrm{~cm}$, cell volume $1 \mathrm{~mL}, \mathrm{Hellma}$ ). The indicated buffer was used to take a baseline scan. In some of the experiments, there was a uniform shift of the baseline across the entire spectral region (200$800 \mathrm{~nm}$ ), which was corrected for during data processing. The concentration of FMN was directly calculated based on the absorbance at $\lambda=445 \mathrm{~nm}\left(\varepsilon=12.50 \mathrm{mM}^{-1} \mathrm{~cm}^{-1}\right)$ and FAD based on the absorbance at $\lambda=450 \mathrm{~nm}\left(\varepsilon=11.30 \mathrm{mM}^{-1} \mathrm{~cm}^{-1}\right)$. The decrease in [oxidised flavin] over time was determined in order to calculate specific initial enzyme activity (discounting any lag phase). ${ }^{[5]}$ 


\section{S2.2. Chiral phase GC-FID to monitor alkene reductions}

Column: CP-Chirasil-Dex CB (Agilent), $25 \mathrm{~m}$ length, $0.25 \mathrm{~mm}$ diameter, $0.25 \mu \mathrm{m}$ (film thickness), fitted with a guard of $10 \mathrm{~m}$ undeactivated fused silica of the same diameter

Carrier: He (CP grade), $170 \mathrm{kPa}$ (constant pressure)

Inlet temperature: $200^{\circ} \mathrm{C}$

Injection conditions: Splitless with split flow $60 \mathrm{~mL} / \mathrm{min}$, splitless time 0.8 mins, purge 5 $\mathrm{mL} / \mathrm{min}$. Injection volume $=0.5 \mu \mathrm{L}$.

Detection: FID $\left(\mathrm{H}_{2}=35 \mathrm{~mL} / \mathrm{min}\right.$, air $=350 \mathrm{~mL} / \mathrm{min}$, makeup $\mathrm{N}_{2}=40 \mathrm{~mL} / \mathrm{min}$, temp $\left.=200{ }^{\circ} \mathrm{C}\right)$ Oven heating profile:

\begin{tabular}{|c|c|}
\hline Time (minutes) & Temperature \\
\hline $0 \rightarrow 5$ & Hold at $70^{\circ} \mathrm{C}$ \\
\hline $5 \rightarrow 30$ & Ramp to $120^{\circ} \mathrm{C}$ at $2{ }^{\circ} \mathrm{C} / \mathrm{min}$ \\
\hline $30 \rightarrow 36$ & Ramp to $180^{\circ} \mathrm{C}$ at $10^{\circ} \mathrm{C} / \mathrm{min}$ \\
\hline $36 \rightarrow 45$ & Hold at $180^{\circ} \mathrm{C}$ for 5 minutes \\
\hline
\end{tabular}

Compound retention times (reduction of $\mathbf{1}$ ):

Time (minutes) $\quad$ Compound

12.27

12.68

Ketoisophorone (1)

12.80

$(R)$-Levodione (2)

(S)-Levodione (2) 


\section{S3. Experimental procedures}

All experiments were carried out in a glovebox (Glove Box Technology Ltd) under a protective $\mathrm{N}_{2}$ atmosphere $\left(\mathrm{O}_{2}<0.1 \mathrm{ppm}\right)$. Stock solutions of FAD and FMN were prepared using deoxygenated buffer. Different concentrations of stock solutions of 1 were prepared in DMSO such that DMSO was $1 \mathrm{vol} \%$ in the final reaction mixture.

\section{S3.1. General Procedure A (Flavin reduction)}

The indicated volume of Tris- $\mathrm{HCl}$ buffer $(50 \mathrm{mM}, \mathrm{pH} 8.0)$ or phosphate buffer $(50 \mathrm{mM}, \mathrm{pH}$ 8.0) was added to a UV-visible quartz cuvette, which was placed in the cell holder and allowed to warm to the indicated temperature (pre-set on the Peltier accessory) for $5 \mathrm{~min}$. A baseline was recorded using the UV-visible spectrophotometer (see S2.1). A solution of 0.1 $\mathrm{mM}$ flavin (unless otherwise noted) in the designated buffer was next prepared in the cuvette, which was then capped with a rubber septum that was pierced with two needles to provide a gas inlet and outlet. An $\mathrm{H}_{2}$-line was then connected and bubbled through the flavin solution via the inlet needle for 10 minutes. The needle was then moved up to the headspace through which a continuous $\mathrm{H}_{2}$ flow was supplied. About $0.4 \mathrm{~mL}$ of the flavin solution was then used to transfer the designated quantity of Hyd1 into the cuvette using a syringe and needle, and the needle and syringe rinsed by drawing solution in and out of the cuvette. The assay was carried out by taking one scan $(200-800 \mathrm{~nm})$ every 30 seconds over 30 minutes.

\section{S3.2. General Procedure B (Alkene reduction)}

Using a syringe and needle, $600 \mu \mathrm{L}$ of $\mathrm{H}_{2}$-saturated Tris- $\mathrm{HCl}$ buffer $\left(50 \mathrm{mM}, \mathrm{pH} 8.0,25^{\circ} \mathrm{C}\right)$ was transferred to a centrifuge tube (Eppendorf, $1.5 \mathrm{~mL}$ ) that contained the required quantities of FMN and 1 in DMSO (1 vol\% DMSO in total reaction mixture). A portion of this solution (approx. $0.2 \mathrm{~mL}$ ) was used to transfer Hyd1 (57 $\mu \mathrm{g}$, activated under $\mathrm{H}_{2}$ for 3-15 h) and TSOYE $(145 \mu \mathrm{g})$ into the reaction tube in sequence via a needle and syringe. The lid of the centrifuge tube was pierced once with a needle, capped, and placed in a Büchi Tinyclave pressure vessel which was then charged to the designated pressure of $\mathrm{H}_{2}$. The pressure vessel was then removed from the glovebox and wrapped in aluminum foil to exclude light in order to prevent photodecomposition of the FMN, flavoenzyme, or both. ${ }^{[6]}$ The vessel was placed on a Stuart ${ }^{\circledR}$ mini see-saw rocker set to 30 oscillations $/ \mathrm{min}$. The extent of conversion and enantiomeric excess (\%ee) of $(R)-2$ was determined by chiral GC-FID (General Procedure C).

\section{S3.3. General Procedure C (Preparing samples for chiral GC analysis)}

Aliquots $(25 \mu \mathrm{L})$ of reaction mixture were taken for analysis at $1 \mathrm{~h}$ and $15 \mathrm{~h}$ (and $24 \mathrm{~h}$ when indicated) then extracted into $200 \mu \mathrm{L}$ EtOAc with $2 \mathrm{mM}$ undecane as an internal standard. The biphasic solution was centrifuged to separate out any solids $(12,000 \times g, 2 \mathrm{~min})$, then $150 \mu \mathrm{L}$ of the EtOAc layer was removed, dried over $\mathrm{Na}_{2} \mathrm{SO}_{4}$ and $75 \mu \mathrm{L}$ of the solution was taken for GC analysis (see S2.2). 


\section{S4. Supplementary data and results}

A

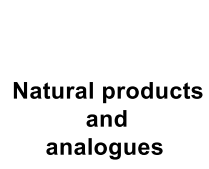

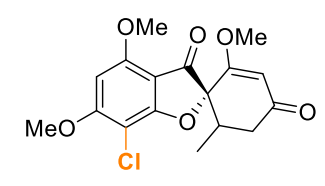

Grisofulvin

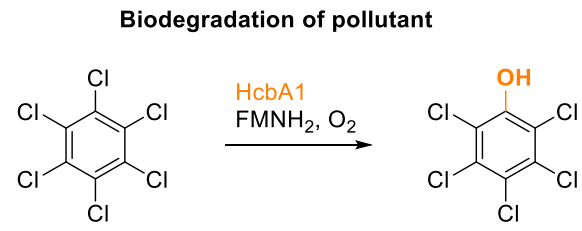

banned fungicide

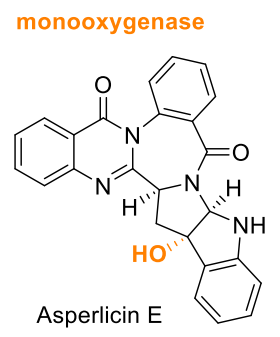

ene-reductase<smiles>CCCOC(=O)CCCC/C=C\C[C@H]1[C@H](O)C[C@@H](O)[C@@H]1/C=C\C[C@H](O)CCc1ccccc1</smiles>

Non-native light driven cyclization<smiles>CN(CCC/C=C/c1ccccc1)C(=O)CCl</smiles>
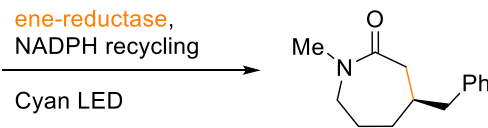

via radical intermediate

Latanoprost

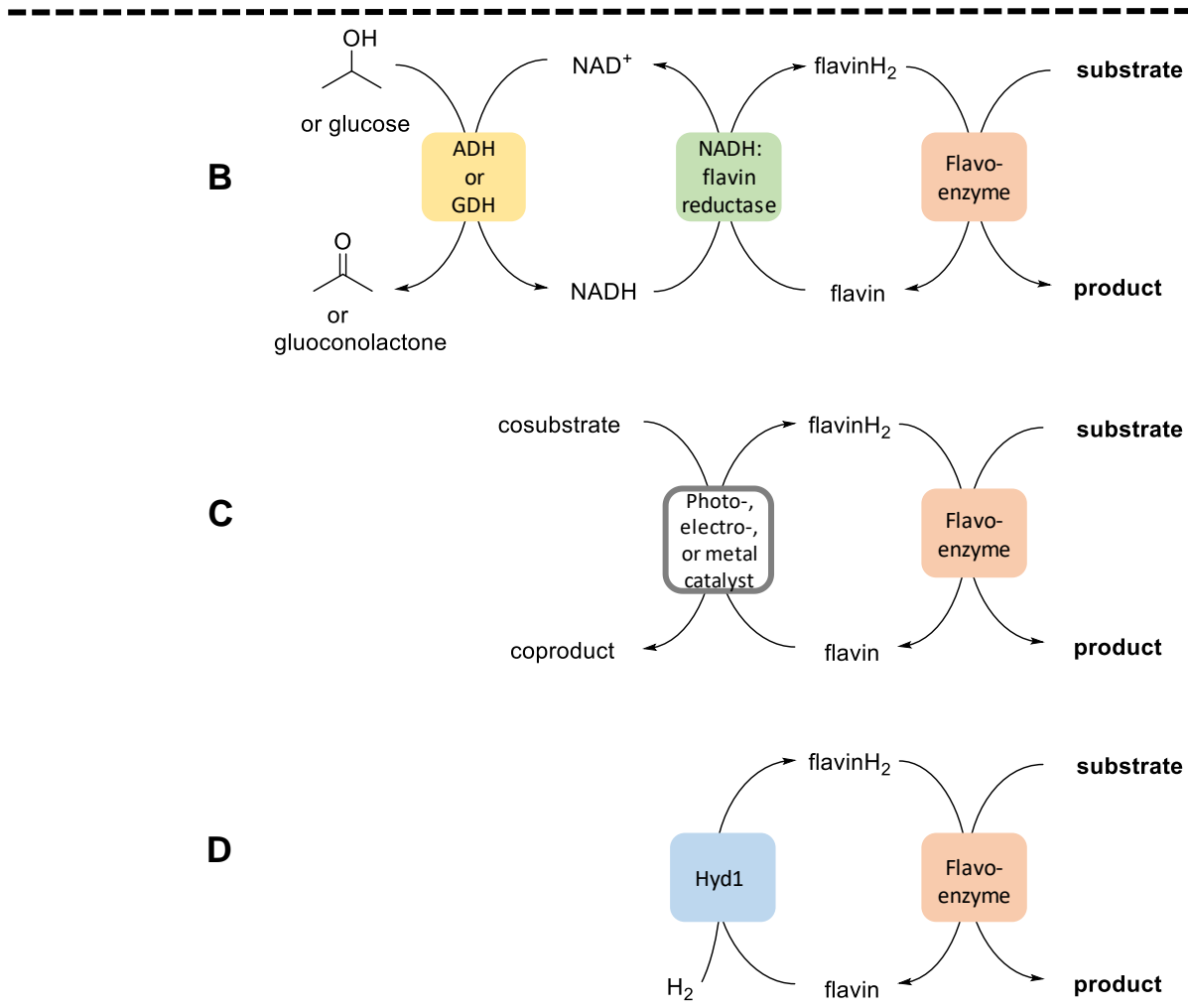

Figure S2. Current applications and methods of flavin recycling

A. Examples of flavoenzymes applied toward natural products and analogues, ${ }^{[7-9]}$ degradation of an environmental pollutant, ${ }^{[10]}$ and a non-native light-driven cyclisation. ${ }^{[11]}$ B. Current enzymatic flavin regeneration methods rely on $\mathrm{NAD}(\mathrm{P}) \mathrm{H}$, which itself is continually regenerated using expensive, carbon-based sacrificial reductants. C. Other catalytic methods for flavin recycling tend to rely on cosubstrate additives. D. (This work) A simplified $\mathrm{H}_{2}$-driven direct flavin reduction method using Hyd1 enzyme. 
S4.1. Control experiments to confirm role of $\mathrm{Hyd} 1$ and $\mathrm{H}_{2}$ in flavin reduction
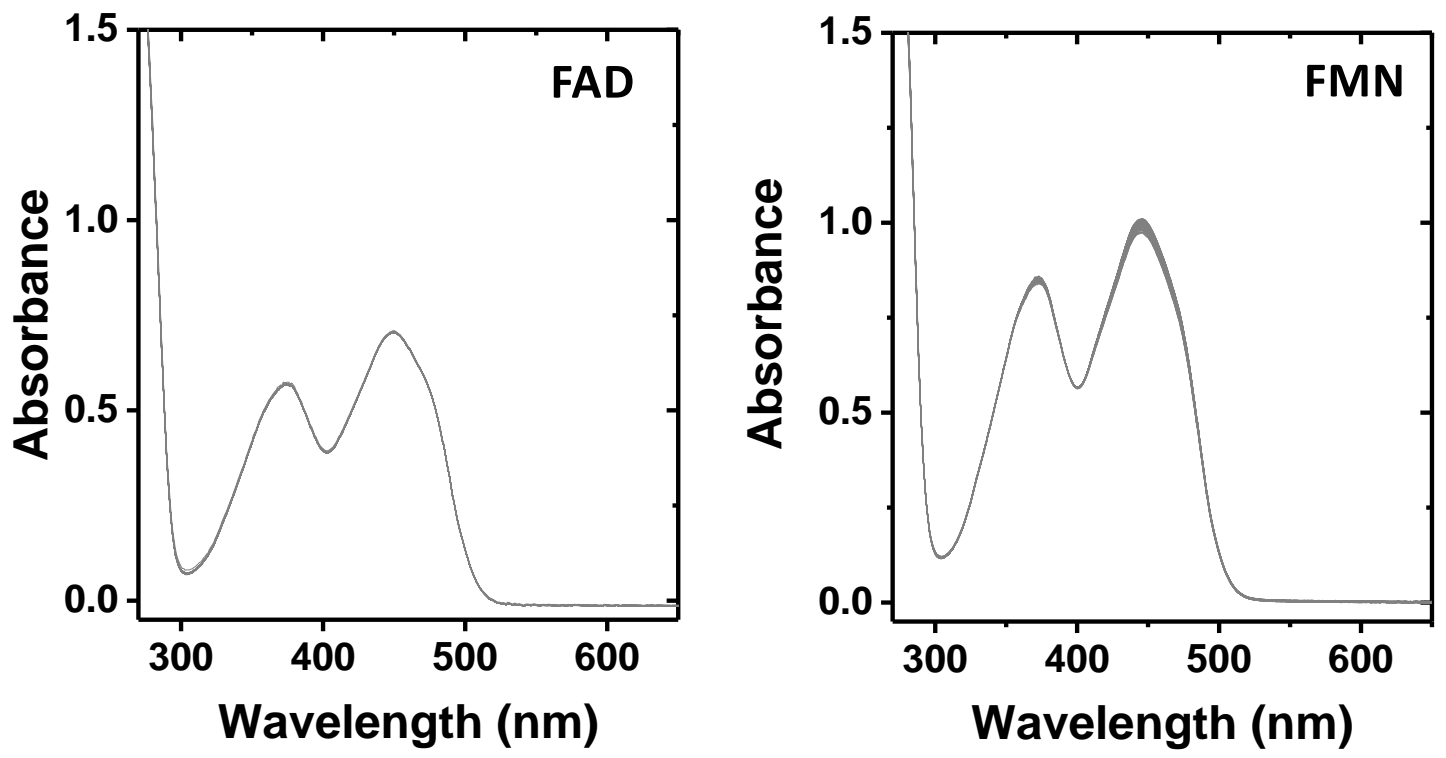

Figure S3. Background flavin reduction in absence of $\mathrm{H}_{2}$

Reaction conditions: $800 \mu \mathrm{L}$ scale, $0.1 \mathrm{mM}$ flavin in Tris- $\mathrm{HCl}$ buffer $\left(50 \mathrm{mM}, \mathrm{pH} 8,25^{\circ} \mathrm{C}\right), 40 \mu \mathrm{g} \mathrm{Hyd} 1$, $25^{\circ} \mathrm{C}$ controlled by Peltier accessory. The Hyd1 specific activity for FAD and FMN reduction during this control reaction was $0.06 \mathrm{nmol} \mathrm{min}^{-1} \mathrm{mg}^{-1}$ and $2.08 \mathrm{nmol} \mathrm{min}^{-1} \mathrm{mg}^{-1}$ respectively.
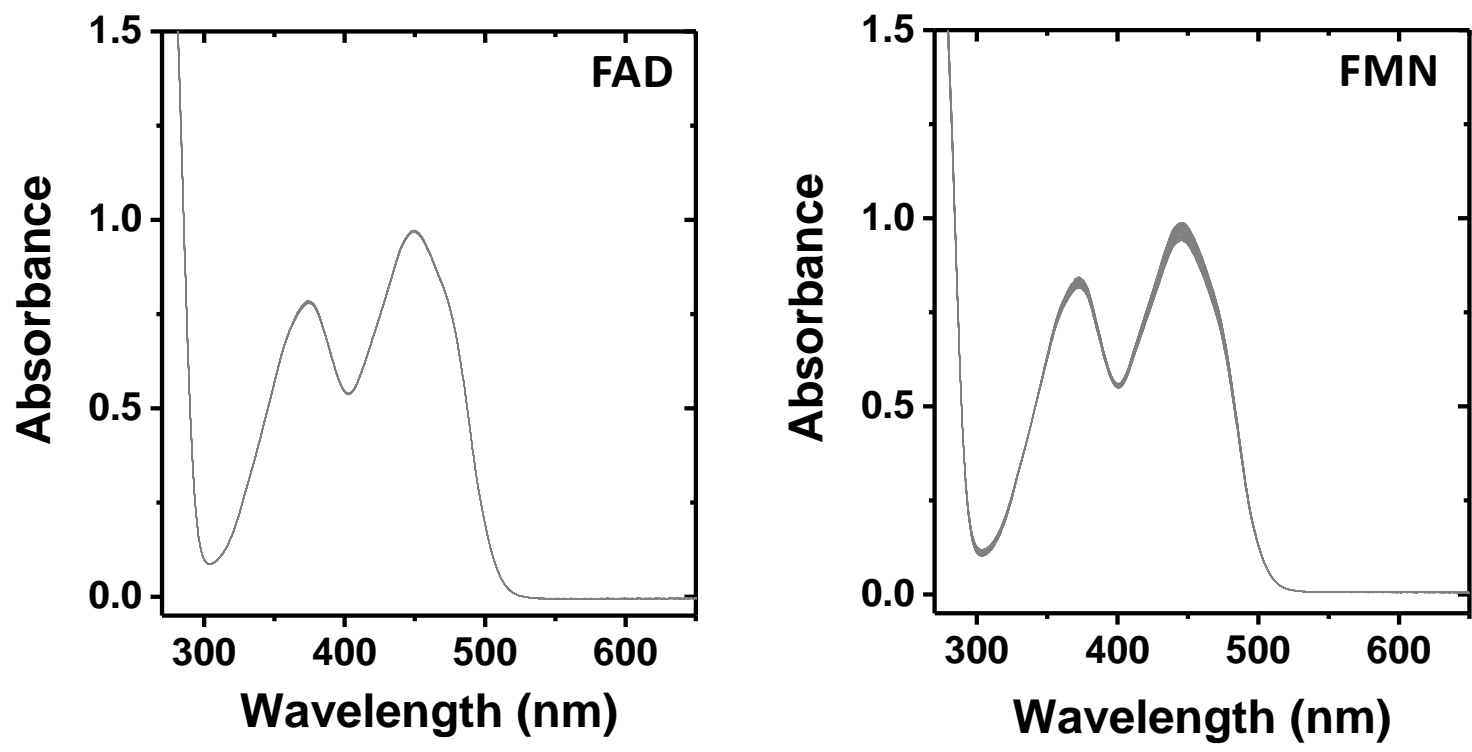

Figure S4. Background flavin reduction in absence of Hyd1

Reaction conditions: $800 \mu \mathrm{L}$ scale, $0.1 \mathrm{mM}$ flavin in Tris- $\mathrm{HCl}$ buffer $\left(50 \mathrm{mM}, \mathrm{pH} 8,25^{\circ} \mathrm{C}\right), \mathrm{H}_{2}$ flow (cuvette head space), $25^{\circ} \mathrm{C}$ controlled by Peltier accessory. The overall decrease in [FAD] and [FMN] amounts to $0.000 \mathrm{mM}$ and $0.005 \mathrm{mM}$ after 30 minutes respectively. 

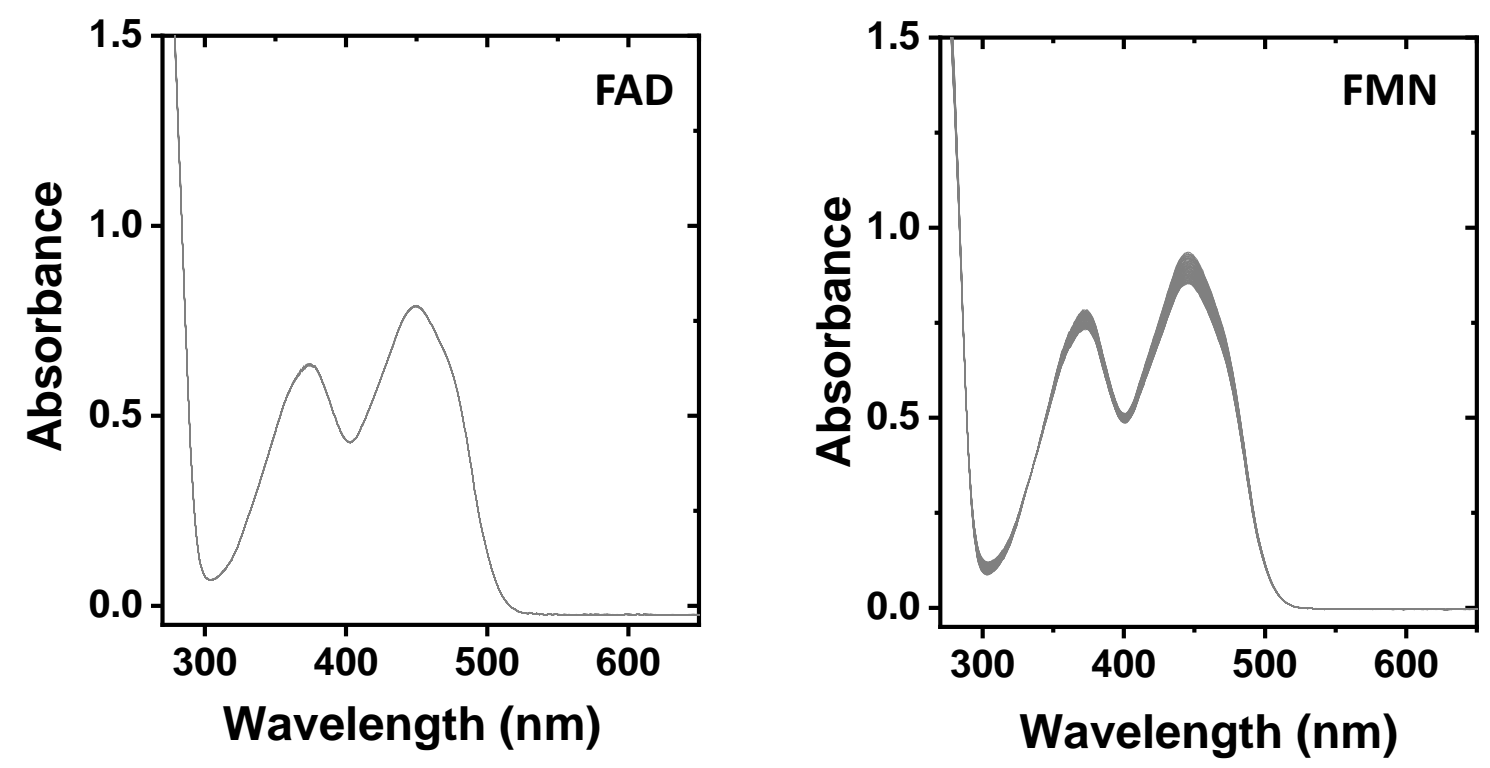

Figure S5. Background flavin reduction in the absence of $\mathrm{H}_{2}$ and Hyd1

Reaction conditions: $800 \mu \mathrm{L}$ scale, $0.1 \mathrm{mM}$ flavin in Tris- $\mathrm{HCl}$ buffer $\left(50 \mathrm{mM}, \mathrm{pH} 8,25^{\circ} \mathrm{C}\right), 25^{\circ} \mathrm{C}$ controlled by Peltier accessory. The overall decrease in [FAD] and [FMN] amounts to $0.000 \mathrm{mM}$ and $0.080 \mathrm{mM}$ after 30 minutes respectively. 
S4.2. Reduction of FMN under $\mathrm{H}_{2}$ using Hyd1 enzyme fractions that contain or are lacking the cytochrome

Experiments were conducted to determine whether the presence of the partner cytochrome, HyaC, impacts the flavin reduction activity. As shown in Figures S6 and S7, the rate of FMN reduction was not affected significantly by the presence or absence of cytochrome. Hyd1 for these experiments was provided by Wangzhe Li and Sophie Kendall-Price (University of Oxford), with advice from Dr Rhiannon Evans (University of Oxford). Hyd1 with cytochrome was separated by gel filtration. Hyd1 without cytochrome was prepared from a strain lacking the hyaC gene.

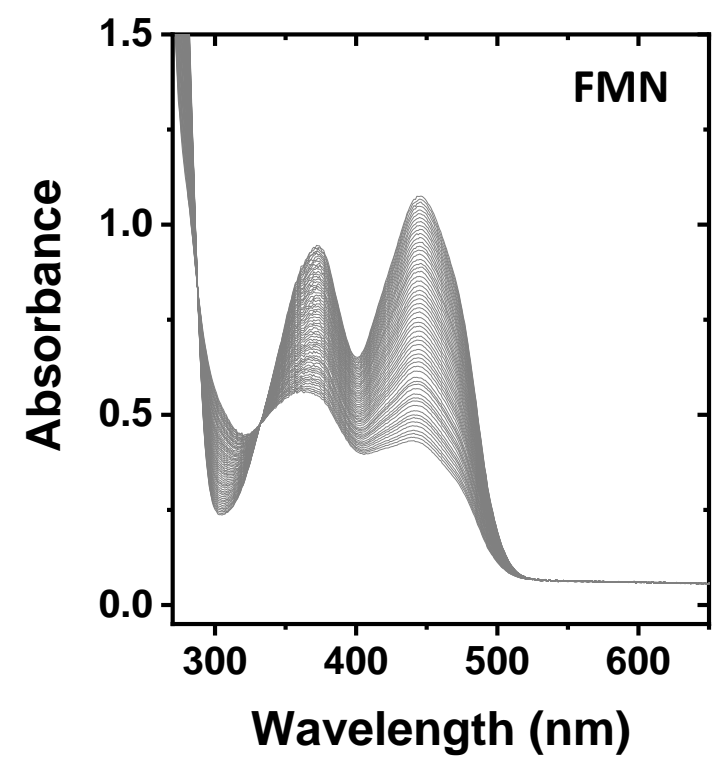

Figure S6. Flavin reduction in the presence of $\mathrm{H}_{2}$ using a Hyd1 sample that does not contain the cytochrome

Reaction conditions: $800 \mu \mathrm{L}$ scale, $0.1 \mathrm{mM}$ FMN in Tris-HCl buffer ( $\left.50 \mathrm{mM}, \mathrm{pH} 8,25^{\circ} \mathrm{C}\right), 40 \mu \mathrm{g}$ Hyd 1 expressed without the cytochrome gene (activated for $16 \mathrm{~h}$ under $\mathrm{H}_{2}$ ), $25^{\circ} \mathrm{C}$ controlled by Peltier accessory. The Hyd1 specific activity observed for FMN for this reaction was $47.5 \mathrm{nmol} \mathrm{min}{ }^{-1} \mathrm{mg}^{-1}$. 


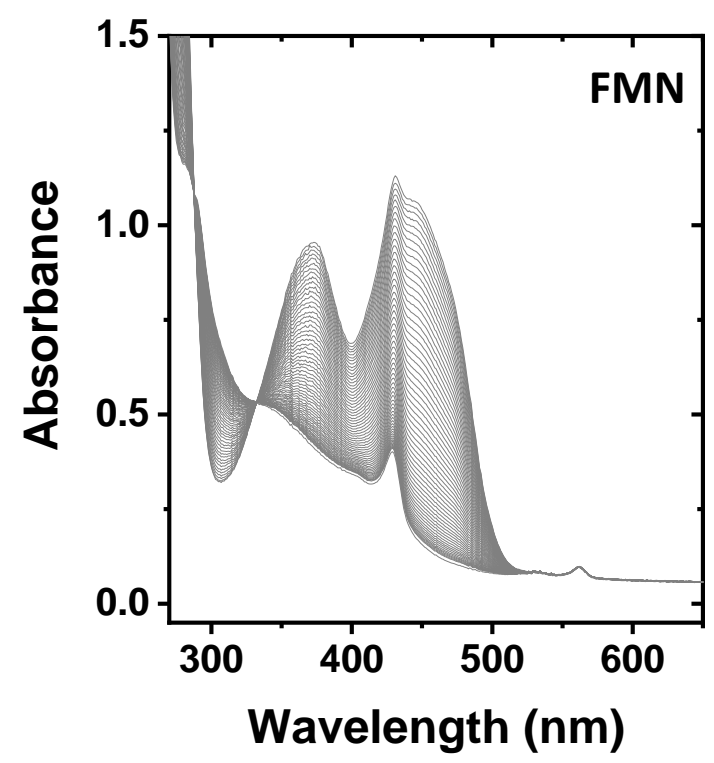

Figure S7. Flavin reduction under the presence of $\mathrm{H}_{2}$ using Hyd1 containing the cytochrome Reaction conditions: $800 \mu \mathrm{L}$ scale, $0.1 \mathrm{mM} \mathrm{FMN}$ in Tris- $\mathrm{HCl}$ buffer $\left(50 \mathrm{mM}, \mathrm{pH} 8,25^{\circ} \mathrm{C}\right), 60 \mu \mathrm{g} \mathrm{Hyd} 1$ containing the cytochrome subunit (activated for $17 \mathrm{~h}$ under $\mathrm{H}_{2}$ ), $25^{\circ} \mathrm{C}$ controlled by Peltier accessory. In this case, an absorbance change for oxidised vs reduced cytochrome is overlaid on the spectral changes from the FMN, giving rise to a sharp peak at around $425 \mathrm{~nm}$. ${ }^{[12]}$ The Hyd1 specific activity observed for FMN reduction in this reaction was $51.6 \mathrm{nmol} \mathrm{min}{ }^{-1} \mathrm{mg}^{-1}$.

\section{S4.3. Complete reduction of $\mathrm{FMN}$ to $\mathrm{FMNH}_{2}$}

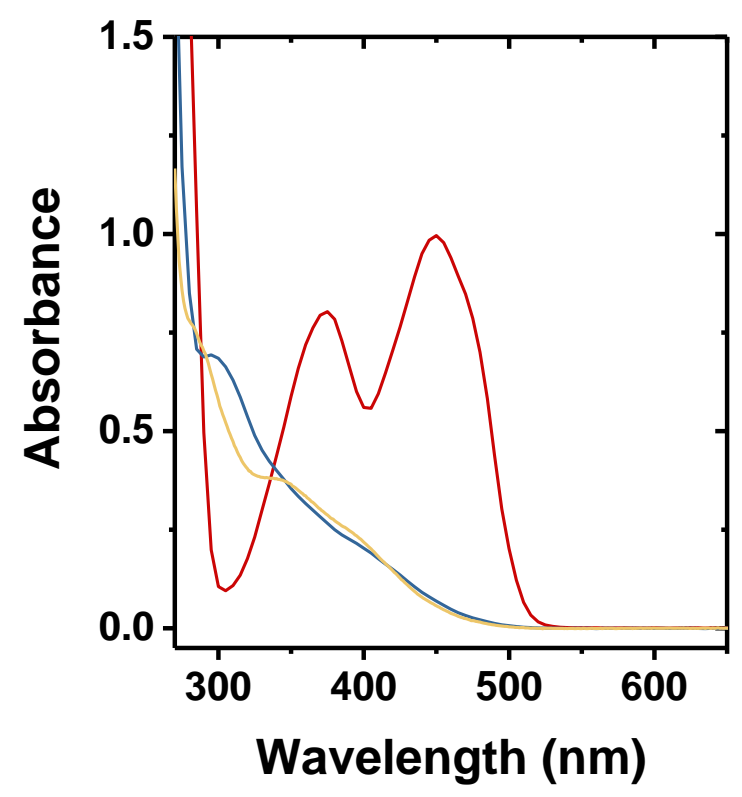

Figure S8. UV-visible spectra of FMN (red) and $\mathrm{FMNH}_{2}$ produced by Hyd1 under $\mathrm{H}_{2}$ (yellow) or sodium dithionite (blue).

Reaction conditions for FMN reduction by Hyd1 (yellow): $800 \mu \mathrm{L}$ scale, $0.1 \mathrm{mM} \mathrm{FMN} \mathrm{in} \mathrm{Tris-HCl} \mathrm{buffer}$

( $50 \mathrm{mM}, \mathrm{pH} 8,25^{\circ} \mathrm{C}$ ), $\mathrm{H}_{2}$ flow (cuvette head space), $57 \mu \mathrm{g} \mathrm{Hyd} 1,25^{\circ} \mathrm{C}$ controlled by Peltier accessory. The full reduction of FMN by Hyd1 was completed during the experiment designed to test the stability of Hyd 1 over time ( $>5$ days).

Reaction conditions for FMN reduction by sodium dithionite (blue): $800 \mu \mathrm{L}$ scale, $0.1 \mathrm{mM}$ FMN in Tris$\mathrm{HCl}$ buffer $\left(50 \mathrm{mM}, \mathrm{pH} 8,25^{\circ} \mathrm{C}\right), 0.15 \mathrm{mM}$ sodium dithionite, $25^{\circ} \mathrm{C}$ controlled by Peltier accessory. 


\section{S4.4. Control experiments for $\mathrm{H}_{2}$-driven ketoisophorone reduction}

Control experiments were performed to see if Hyd1 (entry 1) or TsOYE (entry 2), alone, could lead to 2. In addition, similar experiments were done in the absence of FMN (entry 3) or no enzyme (entry 4). The control experiments demonstrated the need for each reaction component for the reaction to be successful. The results of the experiment are shown in Table S2.

Table S2. Control experiments for $\mathrm{H}_{2}$-driven ketoisophorone reduction

\begin{tabular}{|c|c|c|c|c|}
\hline Entry & FMN & TsOYE & Hyd1 & Conversion to 2 (\%) \\
\hline 1 & $\checkmark$ & - & $\checkmark$ & 0 \\
2 & $\checkmark$ & $\checkmark$ & - & 0 \\
3 & - & $\checkmark$ & $\checkmark$ & 0 \\
4 & $\checkmark$ & - & - & 0 \\
\hline
\end{tabular}

Reaction conditions: $600 \mu \mathrm{L}$ scale, $0.1 \mathrm{mM}$ FMN, $57 \mu \mathrm{g} \mathrm{Hyd1}$, TsOYE $(145 \mu \mathrm{g}), 10 \mathrm{mM}$ 1, Tris-HCl buffer $\left(50 \mathrm{mM}, \mathrm{pH} 8.0,25^{\circ} \mathrm{C}\right), 1$ vol\% DMSO at ambient temperature in pressure vessel $\left(1 \mathrm{bar}_{2}\right)$, $24 \mathrm{~h}$. 
S4.5. Exemplary chiral-phase GC-FID spectra of enzymatic $\mathrm{H}_{2}$-driven reduction of ketoisophorone to $(R)$-levodione

Reduction of 1 (entry 4, Table 1) was carried out and the reaction mixture was analysed by chiral GC-FID according to General Procedure C (see S3.3). Conversion to 1 and the enantiomeric excess (\%ee) were calculated based on the peak area of their respective peaks as shown in Figure S9.

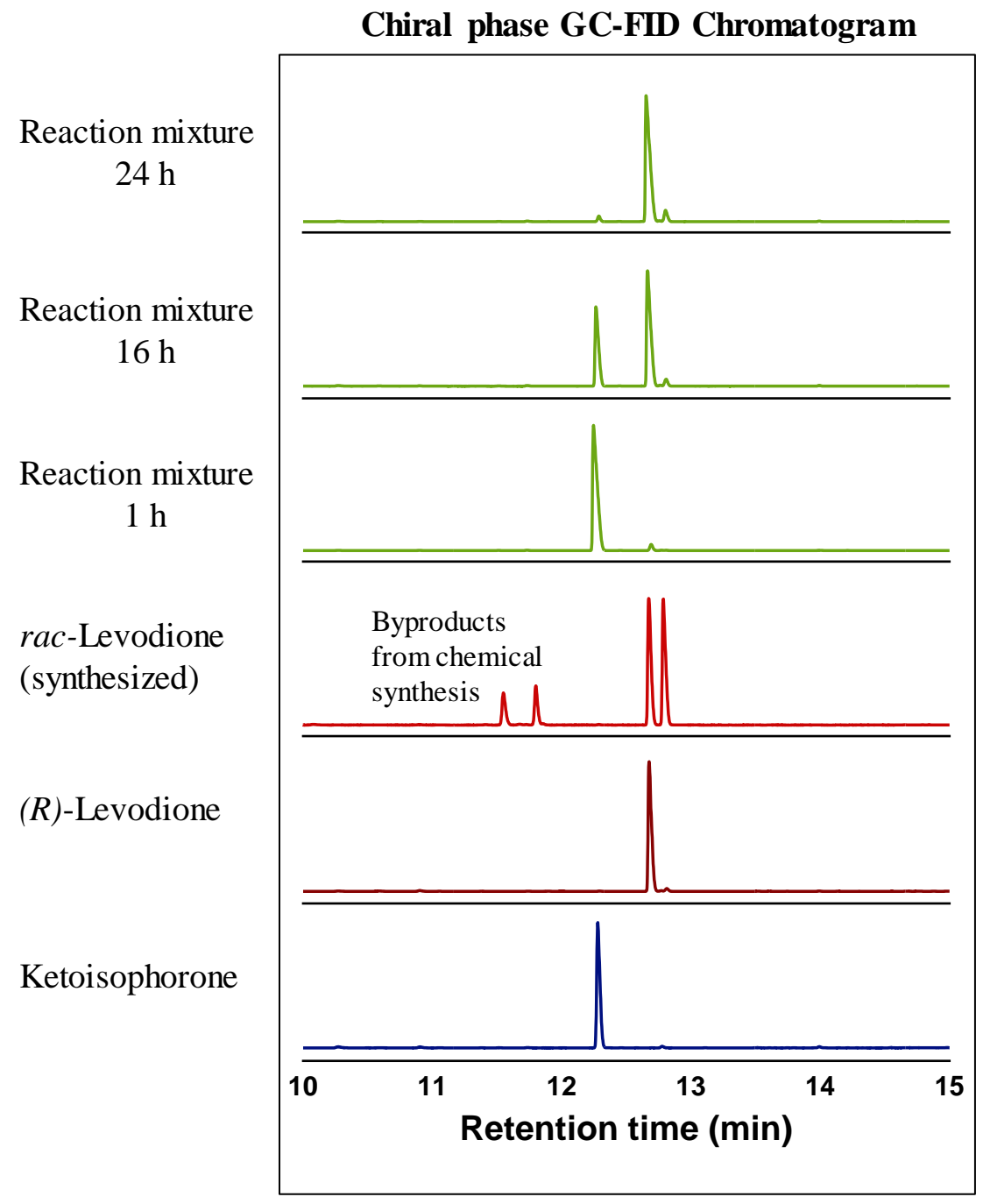

Figure S9. GC-FID results of ketoisophorone reductions (green). Ketoisophorone (purple, commercially available in $\geq 98 \%$ purity), (rac)-levodione (red, synthesised following literature procedure $)^{[1]}$ and $(R)$-levodione (burgundy, obtained from Baker's yeast fermentation) standards were diluted using EtOAc with $2 \mathrm{mM}$ undecane as internal standard. 


\section{S5. Supporting References}

[1] S. Mathew, M. Trajkovic, H. Kumar, Q.-T. Nguyen, M. W. Fraaije, Chem. Commun. 2018, 54, 11208-11211.

[2] H. A. Reeve, L. Lauterbach, O. Lenz, K. A. Vincent, ChemCatChem 2015, 7, 34803487.

[3] D. Johannes Opperman, L. Ann Piater, E. van Heerden, J. Bacteriol. 2008, 190, 3076-3082.

[4] D. J. Opperman, B. T. Sewell, D. Litthauer, M. N. Isupov, J. A. Littlechild, E. van Heerden, Biochem. Biophys. Res. Commun. 2010, 393, 426-431.

[5] P. Macheroux, in Methods Mol. Biol. (Eds.: S.K. Chapman, G.A. Reid), Humana Press, Totowa, NJ, 1999, pp. 1-7.

[6] M. C. R. Rauch, M. Pesic, M. M. E. Huijbers, M. Pabst, C. E. Paul, M. Pešić, I. W. C. E. Arends, F. Hollmann, BBA- Proteins Proteom. 2020, 1868, 140303.

[7] R. A. Cacho, Y. H. Chooi, H. Zhou, Y. Tang, ACS Chem. Biol. 2013, 8, 2322-2330.

[8] M. L. Contente, P. Zambelli, S. Galafassi, L. Tamborini, A. Pinto, P. Conti, F. Molinari, D. Romano, J. Mol. Catal. B.-Enzym. 2015, 114, 7-12.

[9] S. W. Haynes, X. Gao, Y. Tang, C. T. Walsh, J. Am. Chem. Soc. 2012, 134, 1744417447.

[10] S. Adak, T. P. Begley, Biochemistry 2019, 58, 1181-1183.

[11] K. F. Biegasiewicz, S. J. Cooper, X. Gao, D. G. Oblinsky, J. H. Kim, S. E. Garfinkle, L. A. Joyce, B. A. Sandoval, G. D. Scholes, T. K. Hyster, Science 2019, 364, 11661169.

[12] V. Rodríguez-Roldán, J. M. García-Heredia, J. A. Navarro, M. Hervás, B. De la Cerda, F. P. Molina-Heredia, M. A. De la Rosa, Biochem. Biophys. Res. Commun. 2006, 346, 1108-1113. 